\title{
Marketing Pattern of Large Cardamom (Amomum sabulatum) in Tirap District of Arunachal Pradesh, India
}

\author{
Avicha Tangjang and Amod Sharma*
}

Nagaland University, SASRD, Medziphema Campus, District: Dimapur, Nagaland, India

*Corresponding author

\section{A B S T R A C T}

\begin{tabular}{|l|}
\hline Ke y w o r d s \\
Large cardamom, \\
Marketing, \\
Marketing channel, \\
Marketed surplus, \\
Marketable surplus, \\
Marketing cost, \\
Marketing margin, \\
Price spread \\
\hline Article Info \\
\hline $\begin{array}{l}\text { Accepted: } \\
\text { 18 April } 2018 \\
\text { Available Online: } \\
\text { 10 May } 2018\end{array}$ \\
\hline
\end{tabular}

\section{Keywords}

Large cardamom

Marketed surplus,

Marketable surplus

Marketing margin

Article Info

Accepted:

Available Online:

May 2018
A research study on 'marketing of large cardamom in Tirap district of Arunachal Pradesh' was conducted during the year 2014-15, where a 100 respondents were selected from four different villages to represent the population under study. The selected farmers were classified into three groups based on their total land under large cardamom cultivation viz. Category-I (0.10-0.50 ha), Category-II (0.51 to 1.46 ha) and Category-III (= 1.47 ha <). In the study, three different marketing channels were identified in the marketing of the produce, viz., 1. (Channel-I) producer - primary whole seller - secondary wholeseller retailer - consumer. 2. (Channel II) producer - primary wholeseller - retailer - consumer. 3. (Channel III) producer - primary wholeseller - processing unit - secondary wholeseller retailer - consumer. For all the three channels, the marketable surplus was found to be slightly higher than the marketed surplus. Marketing cost was found to be highest in channel 3 ( $\square 22.01 / \mathrm{kg}$.) and least in channel 2( $\square 7.49 / \mathrm{kg}$.) Producers' share in consumer rupee was higher in channel - I (65.92 per cent) as compared to channel - II (58.67per cent) and channel III (58.27per cent). Price spread was also found to be the highest in channel-I ( $\square 507.13 / \mathrm{kg}$ ) and the least in channel III $(\square 153.97 / \mathrm{kg}$.) The marketing efficiency was found to be higher in channel - II compared to channel-I and channel-III when calculated through the conventional method, Sheperd's formula as well as Acharya's model.

\section{Introduction}

Cardamom is among the world's oldest spices, and is the third most expensive spice following saffron and vanilla. The name cardamom is used for herbs within two genera of the ginger family Elettaria (small cardamom) and Amomum (large cardamom). Both varieties take the form of a small seedpod, triangular in cross-section and spindle shaped, with a thin papery outer shell and small black seeds. Elettaria pods are light green in color, while Amomum pods are larger and dark brown (USAID, ACCESO, 2011).

\section{Large Cardamom (Amomum Sabulatum,} Roxb.) is a perennial herbaceous spice crop of Zingiberaceae family and is renounced as Black Gold, Queen of Spices. It is a native to India, Pakistan, Nepal, and Bhutan. It is the world's third-most expensive spice after saffron and vanilla. It is indigenous to moist 
deciduous and semi evergreen forests and is mainly grown in the sub-Himalayan region of India and Nepal (Government of Nepal, Ministry of Agricultural Development Agribusiness Promotion and Statistics Division International Trade Promotion Section July, 2015). Being a low-volume, high-value crop, large cardamom farming is one of the important livelihood sources for mountain people in the Himalayan region. In India, Sikkim is the principal producer of the spice, and is the first state in India to have fully organic farming activity Organicallygrown large cardamom may be priced higher than its fertiliser-fed counterpart, but the former has burgeoning premium-class consumers abroad, whose number is increasing of late, Hence, it is priced higher than the smaller cardamom grown elsewhere in the country. India exported 665 tonnes of large cardamom in 2014-15. Sikkim, which grows large cardamom in 17,000 hectares of land, produces 4,000 metric tonnes ( $90 \%$ of the country's production) of the spice annually (ET Bureau, 2016). In the first half of 2016 fiscal, the powerful flavouring spice endemic to a certain section of the Himalayan terrain had earned the country Rs 20.11 crore in the international market (Press Trust of India, 2016).

In India, major portion of the crop i.e. 1500$1800 \mathrm{MT}$ is consumed domestically, and the rest is exported to other countries including Australia, Canada, Pakistan, South Africa, United Arab Emirates, the United Kingdom and the United States. In India, large cardamom moves through 2 market channels. In the first, farmers sell cured capsules through aggregators and in the second, farmers sell them through contractors or bidders in an auction center (SFAC 2012). In both channels, the capsules then move on to the wholesalers, then retailers and finally consumers. In India, a major portion of the product is consumed in the domestic market.
The rest is exported to other countries. Cardamom plantations had been established in some parts of Arunachal Pradesh on an experimental basis in the 1980s. The experiment showed positive outcome with 14,770 ha under large cardamom cultivation in the year 2012-2013 and a production of 2954 MT in the same year (Directorate of Economics and Statistics, Government of Arunachal Pradesh, 2013).

With an elevation of the area between 600 and $1000 \mathrm{~m}$, and an average rainfall of $250 \mathrm{~cm}$, with average range of temperature between $19^{\circ} \mathrm{C}$ to $25^{\circ} \mathrm{C}$, large cardamom had been introduced in the Tirap district of Arunachal Pradesh on an experimental basis around the same time (Market Research and Planning Cell, Directorate of Marketing and Inspection, Ministry of Agriculture, 1987). However, the commercial cultivation of large cardamom in the said district has been brought under practice only in the past decade. However, it holds great potential and is rapidly gaining widespread popularity with about 295 ha under the cultivation of the particular crop in the year 2015-2016 and a recorded production of $136 \mathrm{MT}$ in the same year (District Horticulture Office record, 2017). Owing to the low volume, high value characteristics of the crop, this area has witnessed a rapid transition from the traditional small scale subsistence farming practiced by the locals to commercial farming of the crop.

Keeping in view the status of large cardamom cultivation in the Tirap district of Arunachal Pradesh the study was undertaken to study the marketing pattern of the crop under the following objectives.

(i) To study the marketable surplus, marketed surplus and marketing channels involved in the marketing of large cardamom,

(ii) To compute the price spread and marketing efficiency of large cardamom. 


\section{Materials and Methods}

For the purpose of fulfilling the objectives of the study, both primary and secondary data were collected through reliable resources. For the collection of the primary data, two blocks viz. Lazu and Dadam were purposefully selected from Tirap district for the study due to the presence of large number of large cardamom growers and a list of villages growing large cardamom commercially from the two selected blocks was then drawn from which, four villages were selected using random sampling method. Lists of large cardamom growers were then obtained from the village heads and village elders of the respective villages and twenty-five large cardamom growers from each village were selected using simple random sampling method to obtain a list of one-hundred respondents to be interviewed using a predesigned set of questionnaires.

The secondary data was collected from the office of the D.A.O. of Tirap, office of the NERCORMP, Khonsa, etc.

\section{Analytical techniques and tools}

Collected data was scrutinized, tabulated and processed systematically according to the objectives laid down for the study. Tabular and functional analysis was used to meet the objectives of the study as and where needed.

\section{Marketed surplus and marketable surplus}

The following formula was used in order to estimate marketable surplus of large cardamom under the study area:

MS $=\mathbf{T P}-\mathbf{T R}$

Whereas: MS = Marketable Surplus

$\mathrm{TP}=$ Total Production

$\mathrm{TR}=$ Total Requirement (Home consumption, seed, gifts, kind, payments, etc).

The marketed surplus (MT) was estimated as follows:

MS' = Actual amount of produce sold in the market irrespective of the farm and family requirement.

$\mathbf{M S}^{\prime}=\mathbf{T P}-(\mathbf{A 1}+\mathbf{A 2})$

Where, MS': Marketed Surplus

$\mathrm{TP}=$ Total Production

$\mathrm{A} 1=$ Actual amount used for farm and family use

$\mathrm{A} 2=$ losses incurred during post-harvest handling and marketing

\section{Marketing cost, margins and price spreads}

Marketing cost was calculated by estimating the cost incurred in the marketing of large cardamom. The cost incurred after harvesting of the yield till it reaches the final consumers hand generally constitutes the marketing cost. It includes transportation cost, handling cost, storage cost, market fees, weighing charges and labour charges for packing, loading and unloading. The marketing cost at various stages of chilli marketing was calculated and finally the total cost was computed.

Absolute marketing margin of its intermediaries at any stages of marketing was calculated as follows.

$\mathbf{M M i}=\mathbf{S P}_{\mathbf{i}}-\left(\mathbf{P P}_{\mathbf{i}}-\mathbf{M C}_{\mathbf{i}}\right)$

Wherein:

$\mathrm{MM}_{\mathrm{i}}=$ Marketing margin of the $\mathrm{i}^{\text {th }}$ middlemen

$\mathrm{SP}_{\mathrm{i}}=$ Selling price of the $\mathrm{i}^{-{ }^{\text {th }}}$ middlemen

$\mathrm{PP}_{\mathrm{i}}=$ Purchase price of the $\mathrm{i}^{\text {th }}$ middlemen

$\mathrm{MC}_{\mathrm{i}}=$ Marketing cost incurred by the $\mathrm{i}^{\text {th }}{ }^{\text {th }}$ middlemen

After the calculation of the marketing margins 
at different stages, finally the total marketing margins was calculated.

\section{Price spread}

Price spread is the difference between the price paid by the consumer and the net price received by the producer. It may consist of marketing costs and margin the price spread analysis was carried out as follows:

Producer'share in consumer rupee $=(($ Producer's price's $) /($ Consumer's price $)) X 100$

\section{Marketing efficiency}

Marketing efficiency is essentially the degree of market performanceand the efficiency of various identified marketing channels was calculated using three different methods viz. Conventional method, Sheperd's formula and Acharya's model. The formulas used are as follows

\section{Ratio of output to input (Conventional method)}

$\mathrm{ME}=\mathrm{O} / \mathrm{I}$ x 100

Where

$\mathrm{ME}=$ Index of marketing efficiency

$\mathrm{O}=$ Value added

$\mathrm{I}=$ Marketing cost

Value added $=$ Difference of the price paid by the consumer to price received by the producers.

\section{Sheperd's formula}

\section{$\mathrm{ME}=\mathrm{CP} / \mathrm{MC}$}

Where

$\mathrm{ME}=$ Index of marketing efficiency

$\mathrm{CP}=$ consumer's purchase price

$\mathrm{MC}=$ Total marketing cost.
Acharya's model

$\mathrm{MME}=\mathrm{FP} /(\mathrm{MC}+\mathrm{MM})$

Where

MME = Modified measure of index of marketing efficiency

$\mathrm{FP}=$ Price received by farmer

$\mathrm{MM}=$ Marketing margin

$\mathrm{MC}=$ Total marketing cost

\section{Results and Discussion}

The data obtained by interviewing the respondents was subjected to various statistical tools and graphs with reference to the set objective in order to obtain a general understanding of the sample population. According to the data collected, the respondents were divided into three categories depending on the land under large cardamom cultivation by the method of grouping the ungrouped data by using mean and standard deviation.

In the study to identify the various Marketing Channels involved in the marketing of large cardamom, three different marketing channels were identified viz.

\section{CHANNEL I: Producer - Primary wholesaler - Secondary wholesaler - Retailer - Consumer}

CHANNEL II: Producer - Primary wholesaler - Retailer - Consumer.

CHANNEL III: Producer - Primary wholesaler - Processing unit - Secondary wholesaler - Retailer - Consumer.

In the study, Channel-III was found to be the longest involving 4 different intermediaries between the producer and the consumer, followed by 3 intermediaries in channel-I and 2 intermediaries in channel-II.

A large portion of the produce i.e. 43.00 per 
cent was transacted through channel-I followed by 29.00 per cent through channel-II and the least through channel-III i.e. 28.00 per cent. The large share of the produce being transacted through channel-I is not due to the effectiveness of the channel, but due to the fact that the primary wholesalers from this particular channel personally go to the producers to collect the produce which encourage the producers to sell their produce to such buyers as it minimizes the producer's marketing cost hence increasing their net income.

The study showed that the marketable surplus was slightly higher than the marketed surplus and almost equal to the yield for all the three categories of farm families. Large cardamom is a spice crop and hence the quantity required for family consumption is very low or almost negligible. Also, the farmers use suckers for propagation purpose. Keeping theses facts in mind, it can be understood that the farm and family requirement of the produce is extremely low and hence the marketable surplus is almost equal to the yield. However, improper post harvest handling of produce, improper curing and storage lead to huge losses causing the marketed surplus to be much lower than the marketable surplus.

The highest marketing cost of the commodity was incurred in channel-III ( $\square .22 .01$ per kg) followed by channel-I ( $\square .14 .56$ per $\mathrm{kg}$ ) and channel-II ( $\square .7 .47$ per kg). Large cardamom is a low-volume high- value crop and hence the marketing cost per unit of produce is relatively low compared to other bulky agricultural produce.

It was also observed that the maximum amount of marketing margin was earned by the primary wholesalers in all the three channels i.e. $\square 304.42$ per $\mathrm{kg}, \square 278.91$ per $\mathrm{kg}$, and $\square 253.26$ per $\mathrm{kg}$ for channerI, channel-II and channel-III respectively. The total marketing margin of all the intermediaries in each channel was found to be the highest in channel-III ( $\square$ 538.90per kg) followed by channel-I ( $\square 496.69$ per $\mathrm{kg}$ ) and the least in channel-II ( $\square 376.69$ per $\mathrm{kg}$ ). This occurrence can be explained by the fact that channel-III has the largest number of intermediaries followed by channel-I and then channel-II. More the number of intermediaries involved in a marketing channel, higher the amount of marketing margin involved in the transaction.

Price spread is the difference between the price paid by the consumer and price received by the producer for an equal amount of produce. The study of price spread involve not only the knowing of actual prices at various stage of marketing channel, but also the cost incurred in the process of movement of produce and the margin of various intermediaries (Acharya and Agarwal, 1987). The price spread was highest in channel-III ( $\square$ 548.63 per $\mathrm{kg}$ ), followed by channel-I ( $\square$ 507.13 per $\mathrm{kg}$ ) and channel-II ( $\square 381.32$ per $\mathrm{kg}$ ). The study also revealed that the producer's share in consumer rupee was highest in channel-II (72.56 per cent) where there were two intermediaries involved, followed by channel-I (65.92 per cent) where there were three intermediaries involved and least in channel-III (65.52 per cent) where there were four intermediaries involved.

Marketing efficiency is essentially the degree of market performance. In this study, three different methods were used to determine the marketing efficiency of the different marketing channels viz. the conventional method, the Shepherd's formula and Acharya's model. In this particular study, marketing efficiency of the different marketing channels involved in the marketing of large cardamom was calculated using all the three above formulas (Table 1-6). 
Table.1 Category of respondents

\begin{tabular}{|c|c|}
\hline CATEGORY & $\begin{array}{c}\text { LAND UNDER LARGE CARDAMOM } \\
\text { CULTIVATION (ha) }\end{array}$ \\
\hline CATEGORY 1 & $0.01-0.5$ \\
\hline CATEGORY 2 & $0.5-1.46$ \\
\hline CATEGORY 3 & $=0.47<$ \\
\hline
\end{tabular}

Table.2 Marketed and marketable surplus

\begin{tabular}{|c|c|c|c|}
\hline CATEGORY & $\begin{array}{c}\text { AVERAGE } \\
\text { YIELD } \\
\text { (kg/farm family) }\end{array}$ & $\begin{array}{c}\text { MARKETABLE } \\
\text { SURPLUS } \\
\text { (kg/farm family) }\end{array}$ & $\begin{array}{c}\text { MARKETED } \\
\text { SURPLUS (kg/farm } \\
\text { family) }\end{array}$ \\
\hline CATEGORY 1 & 154.13 & 154.08 & 149.32 \\
\hline CATEGORY 2 & 334.44 & 334.39 & 329.91 \\
\hline CATEGORY 3 & 564.22 & 564.17 & 559.36 \\
\hline SD & 170.55 & 170.55 & 170.64 \\
\hline
\end{tabular}

Table.3 Marketing cost incurred in different marketing channels

\begin{tabular}{|c|c|c|c|}
\hline CHANNEL & $\begin{array}{c}\text { TOTAL } \\
\text { MARKETING } \\
\text { COST }(\square)\end{array}$ & $\begin{array}{c}\text { QUANTITY OF } \\
\text { PRODUCE } \\
\text { TRANSACTED }(\mathbf{k g})\end{array}$ & $\begin{array}{c}\text { MARKETING COST } \\
(\square / \mathbf{k g})\end{array}$ \\
\hline CHANNEL-I & 188400 & 12943.75 & 14.56 \\
\hline CHANNEL-II & 84000 & 11213.97 & 7.49 \\
\hline CHANNEL-III & 237550 & 10791.89 & 22.01 \\
\hline
\end{tabular}

Table.4 Marketing margin of the intermediaries involved in the different marketing channels

\begin{tabular}{|c|c|c|c|c|c|c|}
\hline CHANNEL & $\begin{array}{c}\text { TOTAL } \\
\text { QUANTITY OF } \\
\text { PRODUCE IN } \\
\text { CIRCULATION } \\
(\text { Kg) }\end{array}$ & $\begin{array}{c}\text { PRIMARY } \\
\text { WHOLESE } \\
\text { LLER } \\
(\square \text { per kg) }\end{array}$ & $\begin{array}{l}\text { PROCESS } \\
\text { ING UNIT } \\
\text { ( } \square \text { per kg) }\end{array}$ & $\begin{array}{c}\text { SECOND } \\
\text { ARY } \\
\text { WHOLES } \\
\text { ELLER } \\
(\square \text { per kg) }\end{array}$ & $\begin{array}{c}\text { RETAILE } \\
\text { R } \\
\text { ( } \square \text { per kg) }\end{array}$ & $\begin{array}{c}\text { TOTAL } \\
\text { ( } \square \text { per } \\
\text { kg) }\end{array}$ \\
\hline CHANNEL -I & 12943.75 & 304.42 & NA & 96.91 & 95.36 & 496.69 \\
\hline CHANNEL -II & 11213.97 & 278.91 & NA & NA & 97.77 & 376.69 \\
\hline CHANNEL -III & 10791.89 & 253.26 & 142.59 & 55.54 & 87.51 & 538.90 \\
\hline TOTAL & 34949.61 & 836.59 & 142.59 & 152.45 & 280.64 & 1412.28 \\
\hline SD & - & 810838.20 & 0 & 553191.55 & 145063.67 & - \\
\hline
\end{tabular}


Table.5 Price spread involved in different marketing channels

\begin{tabular}{|c|c|c|c|c|c|}
\hline CHANNEL & $\begin{array}{c}\text { PRICE PAID } \\
\text { BY } \\
\text { CONSUMER } \\
(\square)\end{array}$ & $\begin{array}{c}\text { PRICE } \\
\text { RECEIVED } \\
\text { BY } \\
\text { PRODUCER } \\
(\square)\end{array}$ & $\begin{array}{c}\text { PRICE } \\
\text { SPREAD } \\
(\square)\end{array}$ & $\begin{array}{c}\text { TOTAL } \\
\text { QUANTITY OF } \\
\text { PRODUCE IN } \\
\text { CIRCULATION }\end{array}$ & $\begin{array}{c}\text { PRICE } \\
\text { SPREAD } \\
\text { ( } \square / \mathbf{k g})\end{array}$ \\
\hline CHANNEL-I & 19415625.00 & 12851503.00 & 6564122.00 & 12943.75 & 507.13 \\
\hline CHANNEL-II & 15699558.00 & 11423421.50 & 4276136.50 & 11213.97 & 381.32 \\
\hline CHANNEL-III & 17267024.00 & 11346289.75 & 5920734.25 & 10791.89 & 548.63 \\
\hline
\end{tabular}

Table.6 Producer's share in consumer rupees

\begin{tabular}{|c|c|c|c|}
\hline CHANNEL & $\begin{array}{c}\text { PRICE RECEIVED } \\
\text { BY THE } \\
\text { PRODUCER } \\
\text { ( } \square \text { per kg) }\end{array}$ & $\begin{array}{c}\text { PRICE PAID BY } \\
\text { THE CONSUMER } \\
\text { ( } \square \text { per kg) }\end{array}$ & $\begin{array}{c}\text { PRODUCER'S } \\
\text { SHARE IN } \\
\text { CONSUMER } \\
\text { RUPEES }\end{array}$ \\
\hline CHANNEL-I & 65.92 & 1500 & 65.92 \\
\hline CHANNEL-II & 58.67 & 1400 & 72.56 \\
\hline CHANNEL -III & 58.27 & 1600 & 65.52 \\
\hline
\end{tabular}

Table.7 Marketing efficiency of different marketing channels

\begin{tabular}{|c|c|c|c|}
\hline CHANNEL & $\begin{array}{c}\text { METHOD 1: } \\
\text { CONVENTIONAL } \\
\text { METHOD }\end{array}$ & $\begin{array}{c}\text { METHOD 2: } \\
\text { SHEPHERD'S } \\
\text { FORMULA }\end{array}$ & $\begin{array}{c}\text { METHOD 3: } \\
\text { ACHARYA'S } \\
\text { MODEL }\end{array}$ \\
\hline CHANNEL-I & 34.84 & 103.06 & 1.94 \\
\hline CHANNEL-II & 50.91 & 186.9 & 2.64 \\
\hline CHANNEL -III & 24.92 & 72.69 & 1.87 \\
\hline
\end{tabular}

Table 7 represents the marketing efficiency of the different channels by using the conventional method, the Shepherd's formula as well as Acharya's model. It was observed that the marketing efficiency was highest for channel-II in all the three methods due to the existence of the least number of intermediaries in the channel compared to the others. It was followed by channel-I where there are three intermediaries involved and channel-III was found to be the least effective of them all as it involved a large number of intermediaries In conclusion, the large cardamom produced in the study area was found to be transacted through three different marketing channels viz. (1) Channel-I: Producer - Primary wholesaler - Secondary wholesaler - Retailer Consumer. (2)Channel-II: Producer - Primary wholesaler - Retailer - Consumer, (3) Channel-III: Producer - Primary wholesaler Processing unit - Secondary wholesaler Retailer - Consumer. Marketable surplus of the produce was found to be more than the marketed surplus due to large amount of post harvest losses. The marketing cost of the commodity was found to be highest for channel-III (Rs. 22.01 per $\mathrm{kg}$ ) with the maximum numbers of intermediaries involved, followed by channel-I (Rs. 14.56 per $\mathrm{kg}$ ) and channel-II (Rs. 7.47 per $\mathrm{kg}$ ) with the least number of intermediaries involved. 
Similarly, the marketing margin was also found to be highest in channel-III (Rs. 538.90 per $\mathrm{kg}$ ) followed by channel-I (Rs. 496.69 per $\mathrm{kg}$ ) and the least in channel-II (Rs. 376.69 per $\mathrm{kg}$ ). It was also observed that the primary wholesalers obtained the highest amount of profit in all the three channels i.e. Rs. 304.42 per kg, Rs. 278.91 per kg, and Rs. 253.26 per $\mathrm{kg}$ for channel-I, channel-II and channel-III respectively. The price spread was found to be highest in channel-III (Rs. 548.63 per kg), followed by channel-I (Rs. 507.13 per $\mathrm{kg}$ ) and channel-II (Rs. 381.32 per $\mathrm{kg}$ ). Also the producer's share in consumer rupee was highest in channel-II (72.56 per cent), followed by channel-I (65.92 per cent), and least in channel-III (65.52 per cent). ChannelII was found to be most efficient for moving the commodity from the producer to the consumer, followed by channel-I. Channel-III was found to be the least efficient amongst the three channels.

\section{References}

A Statistical abstract of Arunachal Pradesh2013 by the Directorate of Economics and Statistics, Government of Arunachal Pradesh, Itanagar.

Acharya, S.S and Agarwal, N.L, 1987. Agricultural Marketing in India, New Delhi: Oxford and IBH Company

Anonymous, ET Bureaul Spices Board to explore global market for large cardamom,

http//economictimes.indiatimes.com/arti cleshow/50717200.cms?utm_source=co ntentofinterest\&utm_medium=text\&utm _campaign=cppst. Updated: Jan 25, 2016, 03.32 PM IST

Anonymous. 1987. Marketing of Large Cardamom in India, Market Research and Planning Cell, Directorate of Marketing and Inspection, Ministry of Agriculture, Government of India.

Anonymous, Official records of the District Horticultural Officer on the area and production of major horticultural crops in Tirap district of Arunachal Pradesh, 2017.

Anonymous, Press Trust of India, India's large cardamom demand to rise globally: Spices Board (http://www.businessstandard.com/article/pti-stories/india-slarge-cardamom-demand-to-riseglobally-spices-board-116012500566_1. html) Updated at January 25, 2016 15:48 IST

Anonymous,USAID, ACCESO, market survey\#02 The world market for cardamom, November 2011, pp. 1.

Anonymous. Trade Flow Analysis of Large Cardamom in Eastern Region Government of Nepal, Ministry of Agricultural Development Agribusiness Promotion and Statistics Division International Trade Promotion Section July, 2015.

Arunachal Pradesh at a glance -2013, by the Directorate of Economics and Statistics, Government of Arunachal Pradesh, Itanagar.

Economic review of Arunachal Pradesh-2013, Directorate of Economics and Statistics, Government of Arunachal Pradesh, Itanagar.

\section{How to cite this article:}

Avicha Tangjang and Amod Sharma. 2018. Marketing Pattern of Large Cardamom (Amomum sabulatum) in Tirap District of Arunachal Pradesh. Int.J.Curr.Microbiol.App.Sci. 7(05): 2599-2606. doi: https://doi.org/10.20546/ijcmas.2018.705.300 